\title{
Acquisition of Object Relative Clauses by Turkish Adult Learners of English
}

\section{İngilizceyi Öğrenen Yetişkin Türk Öğrencilerinin Nesne Konumundaki Sıfat Cümleciklerini Edinimi \\ Eser ÖRDEM*}

\begin{abstract}
The acquisition of complex sentences plays an important role in first and second language studies because evidence of complex sentences in the field of theoretical and applied language is still evolving. 40 sophomore and junior students majoring in Translation and Interpreting were involved in the study. Participants first took a standard test, the Michigan test. The aim of this test was to provide homogeneity in the study. The participants then received 5 different data collection tools. First of all, grammaticality judgment test was given to the participants to check to what extent they provided the accuracy of the sentences. Then the participants were asked to make sentences about object relative clauses In the third stage, the participants were asked to produce at least 20 different pictures and sentences. In the fourth stage, they were told to repeat the object relative clause constructions. In the final stage, the participants were given Turkish sentences and be translated into English. At the end of the study, important data about the acquisition of adjective clauses in object position were reached. The results of the study show that most of the participants tended to avoid using ablative prepositions possible due to the effect of first language that uses only one suffix, while they performed far better in accusative case.

Keywords: Complex Sentences, Adjective Clauses, Language Acquisition, Applied Linguistics

$\ddot{\mathrm{O} z}$

Karmaşık cümlelerin edinimi, birinci ve ikinci dil çalışmalarında önemli bir rol oynamaktadır, çünkü teorik ve uygulamalı dil alanındaki karmaşık cümlelerin kanıtları hala gelişmektedir. Çalışmaya 40 ikinci sınıf öğrencisi ve Çevirmenlik ve Çevirmenlik bölümünden mezun olan genç öğrenciler katılmıştır. Katılımcılar ilk önce standart bir test olan Michigan testini aldı. Bu testin amacı, çalışmada homojenliği sağlamaktı. Katılımcılar daha sonra 5 farklı veri toplama aracı aldı. Her şeyden önce, katılımcılara cümlelerin doğruluğunu ne ölçüde sağladıklarını kontrol etmek için gramerlik değerlendirme testi uygulandı. Daha sonra katılımcılardan nesne ile ilgili cümlecikler hakkında cümleler kurmaları istenmiştir. Üçüncü aşamada katılımcılardan en az 20 farklı resim ve cümle üretmeleri istenmiştir. Dördüncü aşamada, nesneye göre yan tümce yapılarını tekrarlamaları söylendi. Son aşamada katılımcılara Türkçe cümleler verildi ve İngilizce'ye çevrildi. Çalışmanın sonunda, nesne sıfat sıfat cümleciklerinin alınmasıyla ilgili önemli verilere ulaşıldı. Çalışmanın sonuçları, katılımcıların çoğunun, sadece bir sonek kullanan ilk dilin etkisinden dolayı mümkün olan ablatif edatları kullanmaktan kaçınma eğiliminde olduklarını göstermektedir.
\end{abstract}

Anahtar Kelimeler: Karmaşık Tümceler, Sıfat Cümlecikleri, Dil Edinimi, Uygulamalı Dilbilim

\section{Introduction}

The relative clauses are among the most complex sentences that concern the theories of linguistics. It can be said that the studies related to the acquisition of relative clauses and have started to increase since 1960s (Andrews, 2007; Chomsky, 1965; Comrie, 1981; De Vries, 2002; Diessel, 2004; Diessel and Tomasello, 2005; Guasti, Vernice and Frank, 2018; Hamilton, 1995; Kornfilt, 1997, 2000a, 2000b; Lehmann, 1986; Ross, 1967; Smith, 1964; Wiechmann, 2015; Wilson, 1963; Young, 2018; Yun et al., 2015). How children and adults acquire and learn complex sentences is still an enigma for cognitive scientists, linguists and neuroscientists, although relative progress has been made. Some linguists have sought to find gradual processes and acquisition of complex sentences. Relative clauses in particular have been the center of discussions in linguistics and second language acquisition studies. Therefore, different theories have been suggested regarding the acquisition of relative clause constructions. The acquisition of relative clauses, which were previously studied theoretically and typologically, still remains a mystery (Andrews, 2007; Chomsky, 1965; Comrie, 1989; Diessel, 2004; Downing, 1978; Duarte et al., 2015; Frank and Ernst, 2018; Gibson, 1998;

\footnotetext{
* Dr. Öğretim Üyesi, Syracuse Üniversitesi, Dil Bilim Bölümü, eserordem@gmail.com
}

Ördem, E. (2020). Acquisition of Object Relative Clauses by Turkish Adult Learners of English, Gaziantep University Journal of Social Sciences, 19 (1), 204-219, Submission Date: 22-09-2019, Acceptance Date: 26-012020. Araştırma Makalesi. 
Hamilton, 1995; Kayne, 1994; Keenan and Comrie, 1977; O'Grady, 2011; Thornton, 2016; Wu, Kaiser and Vasishth, 2018; Wiechmann, 2015). Larsen-Freeman's (1997) complexity theory can also show why certain structures are harder to process, understand and produce. Klein and Purdue (1997) also referred to a similar problem by asking whether natural languages could be simpler or not, and found that producing complex sentences for foreign language learners was a serious barrier owing to the nature of innate human language capacity because perception, memory and attention processes were found as significant variables in these studies by focusing on the simplicity and complexity of tasks called task complexity ( Skehan and Foster, 1997). However, even if task complexity explains the processing of a certain structure, this variable alone may not explicate the main reason for being unable to produce complex structures and constructions. Therefore, Larsen-Freeman and Lynne emphasize that there may be confounding variables that may render explanations regarding language rather complex because researchers in second language are faced with the enigma taking place in cognitive neuroscience. This explanation should not mean that only complex sentences in language hard to understand. However, even a word in literal meaning, metaphors, collocations or even a simple sentence may be hard to comprehend. Therefore, it is possible to see different hypotheses and linguistic theories regarding complexity, complex structures and constructions.

Keenan and Comrie (1977) maintained that relative clauses are composed of hierarchy in terms of processing. This hypothesis is called Noun Phrase Accessibility Hierarchy. Since there are different types of relative clauses, each type has varying degrees of processability. In addition to this hypothesis, Linear Distance Hypothesis has also produced important insights into understanding relative clauses (Hawkins, 1999, 2001; O'Grady, Lee and Choo, 2003; Tarollo and Myhill, 1983). According to this hypothesis, the accessibility can be predicted based on the words between the head and the gap. Another hypothesis that emphasizes the importance of structural distance is that Structural Distance Hypothesis (O'Grady, 1999). This hypothesis takes the distance between the nodes into consideration. Besides these hypotheses, word order also matters in terms of accessibility. If relative clause constructions are similar to canonical word order, then it might be easier to process them (MacDonald and Christiansen, 2002; Tabor, Juliano and Tanenhaus, 1997). Syntactic Prediction Locality Theory is another theoretical assumption that stresses the importance of memory cost (Gibson, 1998). SO Hierarchy Hypothesis developed by Hamilton $(1994,1995)$ entails difficulties of processing. In recent years, construction grammar, corpus linguistics and cognitive linguistics have taken other criteria into consideration. Frequency, entrenchment, schema and exemplars are among the categories and elements that affect acquisition of relative clauses (Bergen and Chang, 2005; Bever, 1970; Bod, 2006; Diessel 2007, Gennari and MacDonald 2008; Wiechmann, 2015). Corpus linguistics in particular discusses the findings and sampling of hypotheses by giving more authentic examples in this sense (Wiechmann, 2015). Although it emerges as a reaction to producer transformational grammar theory, cognitive linguistics and usage-based grammar studies have not developed a very detailed theory of relative clauses (Wiechman, 2015). Studies on acquisition of relative clauses in the discipline of second language have been on the rise in recent decades (Alotaibi, 2016; Frenck-Mestre and Pynte, 2000; Özge et al., 2015; Rahmany and Haghpour, 2015; Yun et al., 2015).

Studies regarding relative clause have been incremental in Turkish context as well (Boran, 2018; Ordem, 2017; Ordem, Özezen, Darancık, Mavaşoğlu and Hadutoğlu 2018; Ozcelik, 2006; Paluluoğlu, 2017; Turan, 2012, 2018; Yas, 2016). However, there are fewer studies on the production of adjective clauses. The data obtained on relative clauses are still largely interpreted within the framework of productive transformational grammar paradigm. 
This study mainly designed a production-based research method to address this shortcoming in the field and aims to test Hamilton's (1994) hypothesis of the subject-object hierarchy. This hypothesis suggests that the object-subject position is easier to obtain than the subject-object position. But this hypothesis needs data and conclusions from different languages. In addition, some of the studies in the literature have been typologically interpreted and some of them have been explained in the context of producer-transformational linguistics. Recently, the results of corpus linguistics have been reinterpreted relative clauses. How to acquire the adjective clauses in the subject and object position remains one of the most important problems of linguistics and language acquisition.

In English, object relative clauses may take different prepositions whose use may be avoided, neglected or forgotten by adult Turkish learners. In Turkish, object relative clauses are produced with the help of only one suffix- dik/dik, which poses a problem for Turkish learners while acquiring English. In addition, there is a full asymmetry in construction of relative clauses between Turkish and English. Besides, English allows more varied constructions in production of relative clauses.

1. The woman that_called the man

(Subject RC)

2. The woman that the man loved _

(Object RC)

3. The woman that the man gave the gift to_

(Indirect Object RC)

4. The woman whom the man is listening to_

(Object of a preposition)

5. The woman whose car was nice

(Genitive RC)

6. The woman who the man is taller than

(Object of Comparison RC)

7. The woman I talked about

(Zero Object RC)

This study intended to show the acquisition of object relative clauses by Turkish adult learners of English. In all objective relative clauses, Turkish, as stated above, uses only a specific suffix. In canonical word order, Turkish utilizes different suffixes to denote cases.In addition, an asymmetrical structure is observed because the predicate in canonical word order is used at the beginning of the sentence. This asymmetric structural movement may affect the acquisition of relative clauses in object position in English. The following sentences were also used in Ordem's study (Ordem, 2017)

Table 1: Canonical and object relative clause word order in Turkish

\begin{tabular}{l|l}
\hline Turkish Canonical Word Order & Object Relative Clause in Turkish \\
\hline Kitab- I oku du- m & Oku- duğu m kitap \\
Book-ACC read PAST 1SG & Read PART 1SG book \\
\hline Kasaba-da yaşı yor um & Yaşa- dığı m kasaba \\
Town-LOC live PROG 1SG & Live PART 1SG town \\
\hline Yatak- tan kalk tı m & Kalk- tığı m yatak \\
Bed - ABL get out of PAST 1SG & Get out of PART 1SG bed \\
\hline Kafe- ye git ti m & Git - tiği m kafe \\
Cafe- DAT go PAST 1SG & go PART 1SG cafe \\
\hline Arkadaş- la konuş tu m & Konuş- tuğu m arkadaş \\
Friend - INSTR speak past 1SG & speak PART 1SG friend \\
\hline
\end{tabular}

However, English retains each preposition in canonical word order and object relative clauses, while direct object relative clause does not need any preposition as shown in Table 2 . English may use different relativizers such as that, which, who, whom in the case of object relative clauses. In addition, because of the addition of prepositions pied-piping or preposition 
stranding can be chosen depending on the context and individual uses. Thus, it can be said that English tends to utilize different relativizers and different preposition positioning in object relative clauses. The following sentences were also used in Ordem's study (Ordem, 2017).

Table 2: Word order of object relative clauses in English

\begin{tabular}{l|l}
\hline Canonical Word Order in English & Zero Relative Clause in English \\
\hline I am reading the book. & The book that I am reading \\
\hline I am living in the town. & $\begin{array}{l}\text { The town which I am living in } \\
\text { The town in which I am living in } \\
\text { The town that I am living in }\end{array}$ \\
\hline I got out of the bed. & $\begin{array}{l}\text { The bed which I got out of } \\
\text { The bed out of which I got } \\
\text { The bed that I got out of }\end{array}$ \\
\hline I went to the cafe. & $\begin{array}{l}\text { The cafe which I went to } \\
\text { The café to which I went } \\
\text { The café that I went to }\end{array}$ \\
\hline I talked with the friend. & $\begin{array}{l}\text { The friend whom I talked with } \\
\text { The friend with I talked } \\
\text { The friend that I talked with }\end{array}$ \\
\hline
\end{tabular}

\section{Research Questions}

1. To what extent can the participants judge object relative clauses as correct based Grammaticality Judgment Test?

2. To what extent can the participants produce object relative clauses orally based on picture tasks?

3. To what extent can the participants repeat object relative clauses accurately?

4. To what extent can the participants translate object relative clauses from Turkish to English?

5. To what extent can the participants produce object relative clauses written based on picture tasks?

\section{Methodology}

This study used quantitative methods to unearth the acquisition level of relative clauses in object positions by using elicited production procedure (Chaudron, 2003; Mackey and Gass, 2005). Elicitation techniques denote various research tasks composed of visual, verbal, written forms that may directly enable researchers to collect data. This technique motivates participants or individuals to express their knowledge, ideas or feelings about a certain topic or theme directly (Barton, 2015). Therefore, various elicitation tasks were used to elicit data from the participants (Chaudron, 2003; Nunan, 1996; Seliger and Shohamy, 1989). In line with this framework, a convenience sampling method was used to collect data. Five instruments were used to unravel the accuracy of the use of object relative clauses. There are five cases that learners should. These cases are mainly composed of accusative, dative, instrumental, ablative and locative. When the sentences in Turkish to translate into Turkish were formed, only basic words with literal meaning were chosen in order to reduce the 
cognitive load because these instruments aimed to measure syntactic complexity rather than lexical complexity.

\section{Participants}

The participants of the study were composed of 40 undergraduates majoring translation and interpreting in their second year. Their mean age was 21 years old. The participants received a 700-hour English in the preparatory program composed of listening, reading, writing, speaking and grammar skills. They also received various field courses such as basic translation skills, syntax and translation theories. Thus, the participants had a threeyear background in English in the department of translation and interpreting.

\section{Procedure}

The researcher reviewed the related literature from different perspectives based on different theories and hypotheses. The participants were given information about the nature of the study. In addition, the necessary instructions were presented to them with some warm-up activities. The participants were told not to use reduction or relativizer 'where' and 'zero relativizer' by giving them some examples to orient them to the study. They were told that they could use relativizers 'that, which, whom and who'. They were not told that the study would measure object relative clauses but would measure only relative clauses. The study was not timed. They were also told that each sentence contained only simple and elementary words so that they could focus on only syntax of relative clause constructions. The study proceeded from recognition/comprehension level to production level.

\section{Data Collection and Analysis}

In psychometrics, there are different types of validity and reliability. In this study, face validity and inter-rater as well as intra-rater reliability of the tests were provided because face validity aims to measure what is supposed to be tested based on subjective experience of researchers (Nevo, 1985; Oluwatayo, 2012). This study also utilized tests that were subjectively formed in the related literature and the researcher's particular area of expertise. Both inter-rater and intra-rater reliability aim to measure consistency and consensus in the ratings by experts in the field and researchers of the study (Brink, 1993; Roberts and Priest, 2006). One expert specializing in second language acquisition was asked to take a role as an inter-rater. For this purpose, Cronbach's alpha was used to provide internal consistency of tests/tools used in the study (Cronbach, 1951). Cronbach's alpha values of the tasks and tests were 0.80 for Grammaticality Judgment Test, 0.75 for Elicited imitation of tasks, 0.70 for Translation of sentences and 0.70 for Picture based production. Thus, it can be said that the range was acceptable.

Since it was important to provide the homogeneity, the participants were given Michigan Test of English Language Proficiency that took 90 minutes to conduct. This test is composed of a 100-item objective test and three parts including grammar (40 items), vocabulary (40 items) and reading (20 items). The inter-rater reliability of test was .96 (Baldauf, 1978; Baldauf and Dowson, 1980). According to Sharp (1979), the range from 0.85 to 1.00 can be assessed as high while interpreting a coefficient of correlation. The validity of the test is measured as .51. Therefore, Michigan Test of English Language Proficiency is considered a reliable test in measuring participants' level in English. The results of the test showed that there was no significant relationship. First of all, a grammaticality judgment test was given to the participants to check the accuracy of the sentences. Then the participants were asked to make sentences about object relative clauses. In the third stage, the participants were asked to produce at least 20 different pictures and sentences. In the fourth stage, they 
were asked to repeat the relative clause constructions in object positions. In the final stage, the participants were given Turkish sentences and be translated into English.

\section{Limitations}

The study is limited to only 40 adult participants. In addition, only object relative clauses were analyzed. Besides, only five data collection tools were used in the study. The participants were also not timed. Another limitation was that the study used only convenience sampling based on volunteer selection out of 130 adult learners of English.

\section{Results}

The overall results of the study show that almost all Turkish participants used relative clauses in accusative case more accurately than other cases and that most of the participants performed at lower level in ablative case. The results in dative, instrumental and locative cases were better than those in the accusative and lower than those in the ablative case.

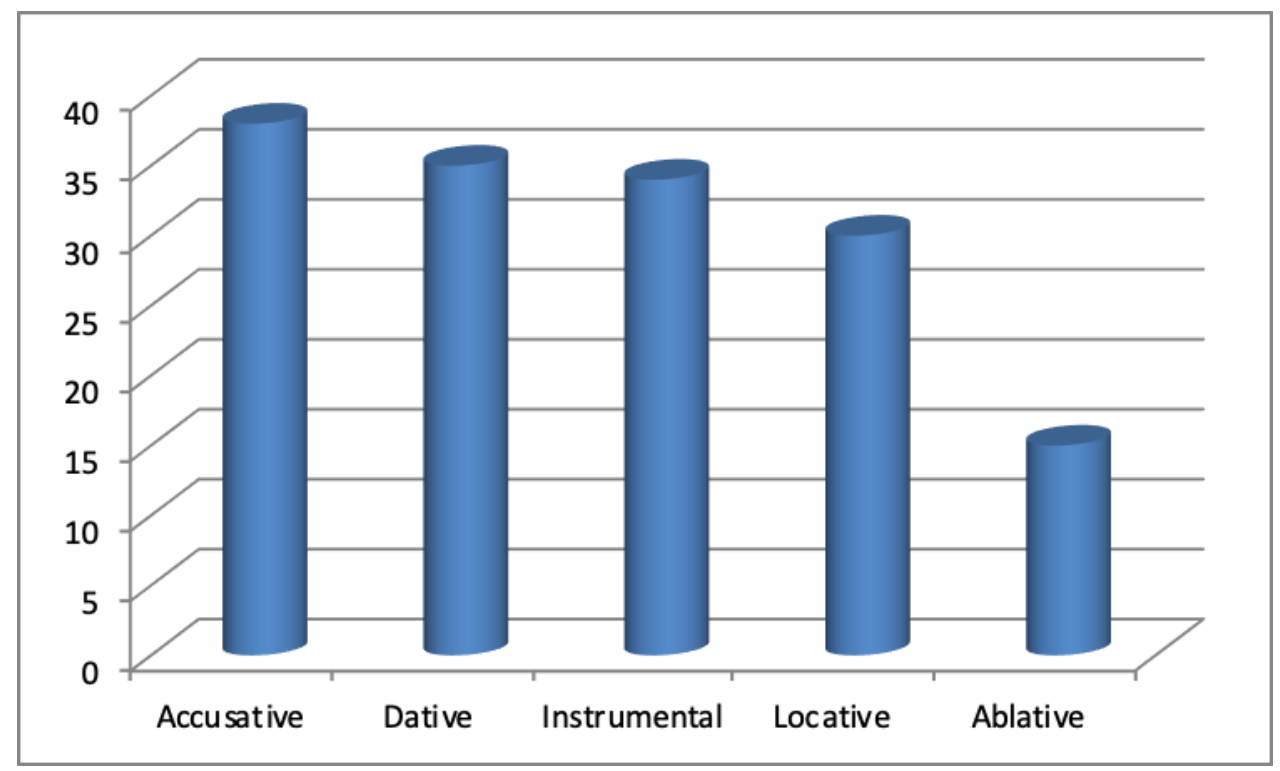

Figure 1: Results of grammaticality judgment test

The results of grammaticality judgment test show that the participants performed much better in accusative and dative case, whereas the lowest scores were obtained in ablative case. The possible reason for this low score in ablative case is that it may entail the use of two prepositions such as away from and out of. In addition, accusative cause does not involve the use of any prepositions. Therefore, it is probable that the participants performed better in accusative. It is clear that when relative clauses entail any preposition, the use of prepositions shows a downward trend. 


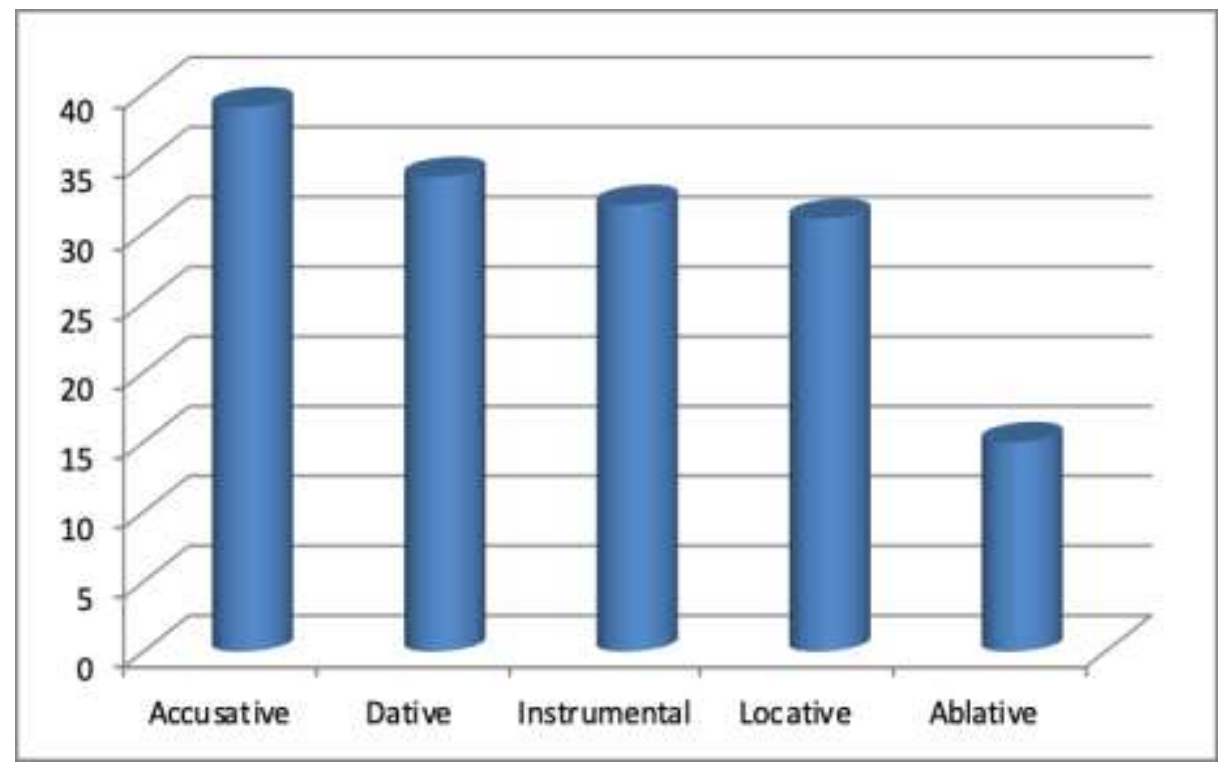

Figure 2: Results of production based on pictures

The results of production based on pictures indicate that the adult learners of English produced accusative case at a much higher percentage, while ablative case was produced at a lower percentage. However, cases of dative, instrumental and locative were relatively high. However, when these cases involve any preposition, some of the participants tend to omit some prepositions because of the possible effect of the first language.

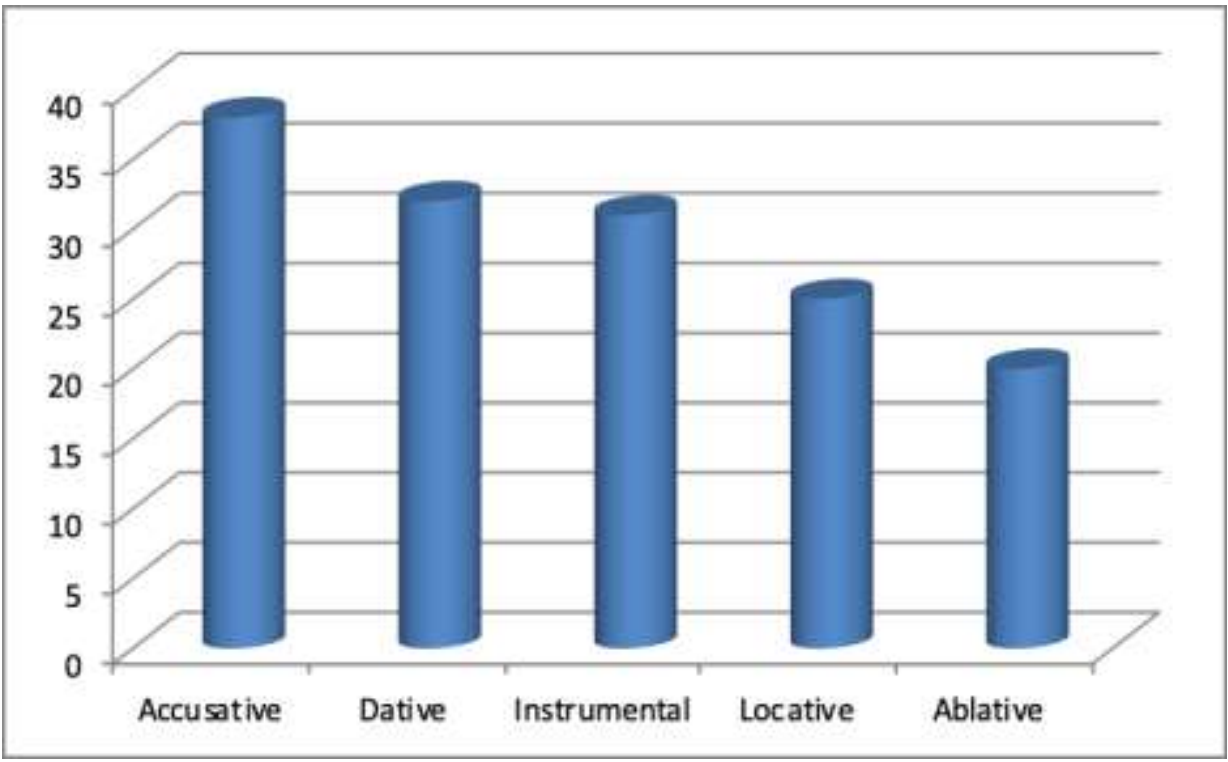

Figure 3: Results of elicited imitation of object relative clauses

Results of repetition of object relative clauses demonstrate that cases of locative and ablative were lower, while accusative case was repeated at a much higher percentage. Cases of dative and instrumental were relatively high. While repeating the sentences, the participants tended to repeat locative and ablative cases less correctly, whereas dative and instrumental cases were repeated more correctly. 


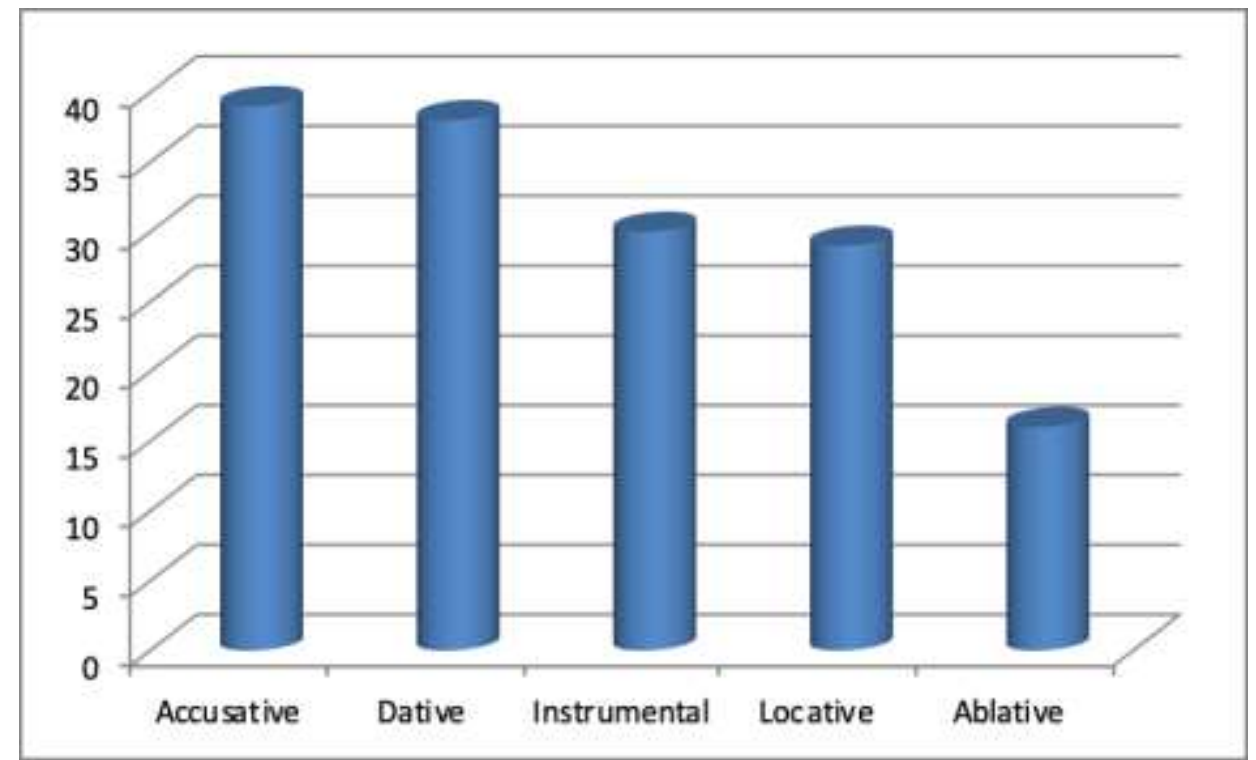

Figure 4: Results of translated sentences from Turkish to English

Results of translated sentences from Turkish to English show that the participants had difficulty translating ablative case at $40 \%$., while they translated almost all of the accusativebased sentences correctly because it is possible that accusative case does not entail the use of any preposition. It can be interpreted that use of any preposition may guide learners to omit or avoid some prepositions in locative and ablative cases in particular.

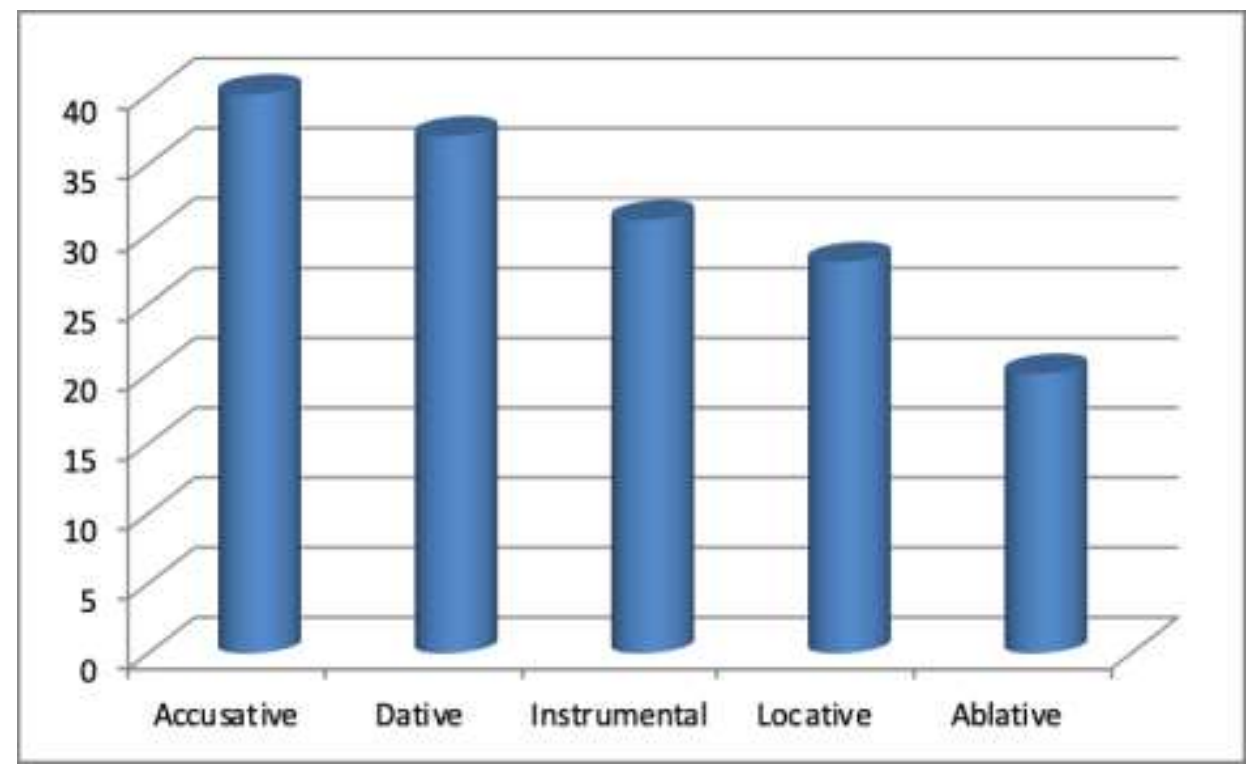

Figure 5: Results of written sentences

Results of written sentences indicate that all of the participants were able to write sentences in accusative case correctly because of the absence of prepositions in this case. However, in ablative case, only half of the participants managed to write sentences in object relative clause constructions correctly.

\section{Discussion}

Since English takes various prepositions in object relative clauses, Turkish learners may have difficulty producing these prepositions in object relative clauses because Turkish language uses only one suffix regardless of any case used in European languages. Although Turkish uses these cases in canonical word order, it reduces these cases into one suffix. 
Wiechmann (2015) ascribes the use of relative clauses to frequency of these cases. However, the effect of first language may also be an important factor while acquiring relative clauses in second language. Since accusative case in English does not take any preposition, it is possible that Turkish participants in this study performed better in accusative case. The use of one suffix in Turkey seems to cause Turkish learners to process object relative constructions. Sánchez-Walker and Montrul (2016) also mention the effect of first language on acquisition of object relative clauses. Housen and Simoens (2016) note that acquisition of relative clause constructions might result from the asymmetry and complexity of these constructions. Ordem (2017) also found that adult Turkish learners of English had difficulty producing certain prepositions in zero relative clause constructions. Wiechmann (2015) also emphasizes that acquisition of object relative clauses may be hard to process. This study also show that the use of prepositions in relative clauses in object position except accusative case may pose a problem for second language learners owing to the possible effect of first language. Other researchers also mentioned the difficulties of acquisition of relative clauses in object position since these constructions are often studied hierarchically (Comrie, 1989; Frank and Ernst, 2018; Gibson, 1998; Hamilton, 1995; Kayne, 1994; Keenan and Comrie, 1977; O'Grady, 2011; Thornton, 2016; Wu, Kaiser and Vasishth, 2018). The findings of these studies are in parallel with this study because prepositions affect the processing of relative clauses in object relative clauses. Similarly, Bardovi-Harling (1987) emphasizes that markedness and salience also play an important role in acquisition of object relative clauses. Mellow (2006) also showed that acquisition of object relative clauses is item-based because less frequently patterns were acquired at a later stage in the participants. Therefore, input frequency was found as a significant predictor in the acquisition of object relative clauses. Yipp and Matthews (1991) found that avoidance in production of relative clauses results from the complexity and hierarchical relations. The results of this study also show that some cases such as ablative were avoided due to the possible hierarchical relations. Alotaibi (2016) also found that the participants from Kuwait had difficulty producing relative clauses in object position when compared to those in subject position. Jach (2018) ascribed processing difficulty of object relative clause to typological differences by taking input frequency and typological similarity into consideration. Some possible difficulties in our study may also result from typological differences and lack of input frequency as well as compositionality problem. Lee (2016) reached similar conclusions by emphasizing transfer effects of the first language. Ulaşan (2018) also found that Turkish learners of English avoided using some relative clauses in their writing. Turan also $(2012,2018)$ found that object relative clauses were harder to process when compared to those in subject position because of the effect of cognitive load.

Different hypotheses regarding relative clause constructions were tested in second language acquisition, and different findings were obtained. However, it is hard to establish a causal correlation between L1 and L2 because it is still a mystery how our brains encode and form complex sentences such as relative clause constructions. Therefore, both first and second language studies on relative clauses have to be confined to hypotheses and models, although corpus linguistics presents more reliable data about only production. Therefore, this study is totally hypothetical and cannot put forward evidence-based findings. The findings of the study show that some cases are perceived more complex and harder to process. These findings partially prove the hypothesis of Larsen-Freeman's (1997) complexity theory and Hamilton's (1994) subject-object theory because certain cases in objects cases are harder to understand and process. This study clearly showed that sentences in accusative case are easier to process since accusative-case based sentences in relative clauses do not entail any preposition. However, if sentences entail prepositions, then acquisition of these structures becomes harder. Thus, it can be said that complexity may stem from consideration and conceptualization of 
morphosyntax of Turkish and syntax of English, which are basically two typologically different languages.

\section{Conclusion}

This study aimed to focus on acquisition of object relative clauses by Turkish adult learners of English. It was found that the participants were better in production and comprehension of accusative relative constructions, while they performed at a lower percentage in ablative case. One of the possible reasons for this result is that in accusative case, object relative clauses in English take no preposition, which seems to facilitate acquisition of these specific constructions. However, as the use of complex prepositions increased, the performance of the participants seemed to have decreased as well. However, this possibility may not explain the main underlying reasons for this low performance. Another possible effect of first language on acquisition of relative clauses can be seen in this study because Turkish, unlike English which uses various prepositions except in accusative case, uses only one suffix in the production of object relative clause constructions. It should be borne in mind that these results cannot be generalized considering the number of languages totaling 7111 ones. Therefore, future studies should concentrate on acquisition of subject relative clauses by making use of corpus linguistics and cognitive linguistics. In addition, new data collection tools can be used in future research to obtain more reliable data and more evidence-based results. Moreover, typologically different languages should be studied so that some generalizations could be obtained, although language studies do not entail generalization because uniqueness and cultural aspects of different languages may always enable researchers to encounter novelty, irregularity and specific constructions as well as unpredictability. Thus, I believe that the mystery regarding how relative clauses are acquired still remains to be solved.

\section{Extended Abstract}

Dil bilim ve ikinci dil edinimi çalışmalarında karmaşık tümcelerin nasıl edinildiği 1950'li yıllardan beri temel problemlerden biri olmuştur. Karmaşık tümceler arasında özellikle sıfat cümleciklerinin edinimi konusunda önemli kuramlar ve hipotezler ortaya atılmıştır. Kuramların büyük çoğunluğu nesne konumunda olan sıfat cümleciklerinin ediniminin daha zor olduğunu ortaya koymuştur. Özne konumundaki cümleciklerinin ediniminin göreceli olarak daha kolay olduğu alan yazında verilere dayalı olarak gösterilmiştir. Alan yazındaki verilere ve sonuçlara dayanarak nesne konumundaki sıfat cümleciklerinin zor olarak belirlenmesi bu çalışmanın gerekçesini oluşturmuştur. LarsenFreeman (1997) karmaşıklık teorisi, bazı yapıların işlenmesinin, anlaşılmasının ve üretilmesinin daha zor olduğunu belirtmektedir. Klein ve Purdue (1997) de doğal dillerin daha basit olup olmadığını sorarak benzer bir soruna değindiler ve yabancı dil öğrenenler için karmaşık cümleler üretmenin doğuştan gelen insan dil kapasitesinin doğası nedeniyle ciddi bir engel olduğunu gördüler. Skehan ve Foster (1997) dil öğretimindeki etkinliklerin doğasına ve yapılış şekline dikkat çekerek sınıf içinde yapılan etkinliklerin basitliği ve karmaşıklığının bu edinim sürecini etkileyebileceklerini göstermeye çalıştılar. Hem kuramsal dil bilimciler hem de uygulamalı dil bilimciler karmaşık cümleciklerinin edinimi ile ilgili farklı perspektifler ortaya koymuşlardır. Bilişsel dil bilim, birinci dil edinimi, ruh dil bilim, hafıza, algı, karmaşa kuramı, kuramsal söz dizimi, sözcük dilbilgisi ve etkinlik temelli çalışmalar sıfat cümleciklerinin edinimi ile ilgili farklı hipotezler geliştirmiş ve bu çalışmaların genel sonuçları özne konumundaki sıfat cümleciklerinin göreceli olarak daha kolay edinildiğini göstermektedir. Nesne konumundaki sıfat cümleciklerinin ise göreceli olarak daha zor işlendiğini, anlaşıldığını ve üretildiğini göstermektedir. Fakat genel olarak dünyada 7111 dil olduğu göz önünde bulundurulacak olursa çalışılan dillerin sayısının azlığına bakılırsa şu aşamada genelleştirilme yapılmasının doğru olmayacağı aşikârdır. 
$\mathrm{Bu}$ çalışma İngilizceyi öğrenen Türk öğrencilerin nesne konumundaki sıfat cümleciklerini ne ölçüde edindiklerini ele almıştır. Türkçe ve İngilizcede sıfat cümleciklerinin dizilimi asimetrik bir eğilim göstermektedir. Ayrıca, Türkçe nesne konumundaki sıfat cümleciklerinde sadece - dik/dik son eki alma eğilimindedir. Oysa İngilizcede akuzatif hali hariç diğer tüm ismin halleri edatlarla kodlanmaktadır. Tipolojik olarak bu temel farklılıktan dolayı birinci dilin ikinci dile etki edeceği düşünülmektedir. Çalışmanın genel hipotezi İngilizcede akuzatif halde sıfat cümleciği herhangi bir edat ile kodlanmadığı için katılımcıların daha iyi performans göstereceği yönündedir. Edat aldığı durumlarda ise katılımcıların performanslarında düşüş yaşanacağı yönündedir. Çalışmada beş veri toplama aracı kullanılmıştır. Dil bilgisel doğruluk testi, resme dayalı sözlü üretim, sıfat cümleciklerinin tekrarı, Türkçeden İngilizceye tümce çevirileri ve sıfat cümleciği içeren tümce yazımı etkinliklerinden oluşmuştur. Çalışmaya 40 lisans öğrencisi katılmıştır ve yaş ortalamaları 21 idi. Katılımcılar dinleme, okuma, yazma, konuşma ve dilbilgisi becerilerinden oluşan hazırlık programında 700 saatlik İngilizce eğitim almışlardır. Ayrıca temel çeviri becerileri, sözdizimi ve çeviri teorileri gibi çeşitli alan dersleri aldılar. Böylece, katılımcıların yazılı ve sözlü çeviri bölümünde üç yıllık İngilizce deneyime sahip olduğu söylenebilir. Katılımcılar ilk önce standart bir test olan Michigan İngilizce Yeterlik testini ald1. Bu testin amacı, katılımcılarda dil düzeyinin homojen olup olmadığını tespit etmekti.

Çalışmanın sonuçları katılımcıların akuzatif halde bulunan sıfat cümleciklerinde çok daha iyi performans gösterdiklerine işaret ederken, çıkma (ablatif) durumunda bulunan sifat cümleciklerinde performanslarının daha düşük olduğu görülmüştür. Bulunma (lokatif) ve araçsal (enstrümental) hallerde ise orta ölçekli bir performans gösterdikleri gözlemlenmiştir. Yönelme (datif) halde ise üretilen sıfat cümleciklerinde ablatif, lokatif ve araçsal hallerle karşılaştırıldığında katılımcıların daha iyi performans gösterdiği fakat akuzatif hali ile karşılaştırıldığında daha düşük performans gösterdikleri tespit edilmiştir. Bu çalışmanın sonuçları sadece Türkçe ve İngilizce ile sınırlı olduğu için katılımcıların akuzatif konumunda daha yüksek performans göstermesi diğer dillerde benzer sonuçların genelleştirilebileceğini iddia etmemektedir.

İkinci dil ediniminde sıfat cümlecikleri yapılarına ilişkin farklı hipotezler test edilmiş ve farklı bulgular elde edilmiştir. Bununla birlikte, birinci dil ve ikinci dil arasında nedensel bir korelasyon kurmak zordur, çünkü beynimizin sıfat cümlecikleri gibi karmaşık cümleleri nasıl kodladığ1 ve oluşturduğu bilimsel olarak hala kanıtlanmamıştır. Bu nedenle, sıfat cümlecikleri ne ilişkin hem birinci hem de ikinci dil çalışmaları hipotez ve modellerle sınırlandırılmalıdır, ancak derlem dilbilimi sadece üretim hakkında daha güvenilir veriler sunar. Bu nedenle, bu çalışma tamamen hipotetiktir ve kanıta dayalı bulgular ortaya koyamaz. Çalışmanın bulguları, bazı hallerin daha karmaşık ve işlenmesi daha zor olarak algılandığını göstermektedir. Bu bulgular, Larsen-Freeman'ın (1997) karmaşıklık teorisinin ve Hamilton'un (1994) özne-nesne teorisinin hipotezini kısmen kanıtlamaktadır, çünkü nesne durumundaki ablatif ve lokatif halleri anlamak ve işlemek daha zordur. Bu çalışma, akuzatif durumdaki cümlelerin işlenmesinin daha kolay olduğunu gösterdi, çünkü sıfat cümlecikleri akuzatif durumda herhangi bir edat gerektirmiyor. Ancak, cümleler edatlar gerektiriyorsa, bu yapıların edinilmesini zorlaştırdığı görülmektedir. Dolayısıyla, karmaşıklığın temel olarak iki tipolojik olarak farklı dil olan Türkçe'nin biçimsözdiziminin ve İngilizce sözdiziminin farklı şekillerde kavramsallaştırılmasından kaynaklandığı söylenebilir.

Gelecekte yapılacak çalışmalarda katılımcı sayısı ve veri toplama araçları arttırılarak daha somut verilere ulaşılabilir. Ayrıca derlem dilbilimin ortaya koyduğu sonuçlar ve dil bilimcilerin kendi oluşturdukları tümceler ve testlerdeki maddeler karşılaştırılarak daha geçerli ve güvenilir sonuçlar elde edilebilir. Türkçenin yanı sıra farklı dillerle çalışarak nesne 
konumundaki sıfat cümleciklerinin başka dillerdeki edinim süreçleri incelenerek farklılıklar ve benzerlikler ortaya konulabilir.

\section{References}

Alotaibi, A. M. (2016). Examining the Learnability of English Relative Clauses: Evidence from Kuwaiti EFL Learners. English Language Teaching, 9(2), 57-65.

Andrews, A. D. (2007). Relative clauses. In T. Shopen (ed.), Language typology and syntactic description, (2nd ed., Vol. 2, pp. 206-236). Cambridge: Cambridge University Press.

Baldauf Jr, R. B. (1978). The Validity of the Michigan Test of English Language Proficiency as a General Measure of High School English Achievement in American Samoa. Educational and Psychological Measurement, 38(2), 429-432.

Baldauf JR, R. B., and Dawson, R. L. (1980). The predictive validity of the Michigan test of English language proficiency for teacher trainees in Papua New Guinea. Educational and Psychological Measurement, 40(4), 1201-1205.

Bardovi- Harlig, K. (1987). Markedness and salience in second language acquisition. Language and Learning, 37(3), 385-407.

Barton, K. C. (2015). Elicitation techniques: Getting people to talk about ideas they don't usually talk about. Theory and Research in Social Education, 43(2), 179-205.

Bergen, B., and Chang, N. (2005). Embodied construction grammar in simulation-based language understanding. Construction Grammars: Cognitive Grounding and Theoretical Extensions, 3, 147-190.

Bever, T. (1970). The cognitive basis for linguistic structures. In J. R. Hayes, (ed.). Cognition and the Development of Language, pp. 279-362. New York: Wiley.

Bod, R. (2006). Exemplar-based syntax: How to get productivity from examples. The Linguistic Review, 23(3), 291-320.

Boran, B. (2018). The role of context on processing of Turkish subject and object relative clauses. Unpublished master thesis, Hacettepe University, Ankara.

Brink, H. I. (1993). Validity and reliability in qualitative research. Curationis, 16(2), 35-38.

Chaudron, C. (2003). Data collection in SLA research. In C. J. Doughty and M. H. Long (Eds.), The handbook of second language acquisition (pp. 762-828). Malden, MA: Blackwell Publishing.

Chomsky, N. (1965). Aspects of the theory of syntax. Cambridge, Massachusetts: MIT Press.

Comrie, B. (1981). The formation of relative clauses. In B. Lloyd and J. Gay (eds.), Universals of Human Thought: Some African Evidence, 215-233. Cambridge: Cambridge University Press.

Comrie, B. (1989). Language universals and linguistic typology. Oxford: Basil Blackwell.

Cronbach, L.J. (1951). Coefficient alpha and the internal structure of tests.Psychometrika, 16 (3). 297-334.

De Vries, M. (2002). The syntax of relativization. Unpublished doctoral dissertation. Utrecht, Netherlands Graduate School of Linguistics.

Diessel, H. (2004). The acquisition of complex sentences. Cambridge: Cambridge University Press. 
Diessel, H. (2007). Frequency effects in language acquisition, language use, and diachronic change. New Ideas in Psychology, 25(2), 108-127.

Diessel, H. and Tomasello, M. (2005). A new look at the acquisition of relative clauses. Language, 81(4), 882-906.

Downing, B. (1978). Some Universals of Relative Clause Structure. In J. Greenberg (ed) Universals of Human Language. (pp. 375-418). Volume 4. Syntax. Stanford, California: University Press.

Duarte, I., Santos, A. L. and Alexandre, N. (2015). How relative are purpose relative clauses?. Probus, 27(2), 237-269.

Frank, S. L. and Ernst, P. (2018). Judgements about double-embedded relative clauses differ between languages. Psychological Research, 83(7), 1-13.

Frenck-Mestre, C. and Pynte, J. (2000). Resolving syntactic ambiguities: Cross-linguistic differences. In M. De Vincenzi and V. Lombardo (eds.). Cross-linguistic Perspectives on Language Processing, (pp. 119-148). Dordrecht: Kluwer Academic.

Gennari, S. P. and MacDonald, M. C. (2008). Semantic indeterminacy in object relative clauses. Journal of Memory and Language, 58(2), 161-187.

Gibson, E. (1998). Linguistic complexity: locality of syntactic dependencies. Cognition, 69, $1-76$.

Guasti, M., Vernice, M. and Franck, J. (2018). Continuity in the adult and children's comprehension of subject and object relative clauses in French and Italian. Languages, $3(3), 24$.

Haig, G. (1997). Turkish relative clauses: A tale of two participles. Turkic Languages, 1(2), 184- 209.

Hamilton, R. (1994). Is implicational generalization unidirectional and maximal? Evidence from relativization instruction in a second language. Language Learning, 44, 123157.

Hamilton, R. L. (1995). The noun phrase accessibility hierarchy in SLA: Determining the basis for its developmental effects. In F. Eckman, D. Highland, P. W. Lee, J. Mileham and R. Weber (eds.), Second language acquisition theory and practice, pp. 101-114. Mahwah, NJ: Lawrence Erlbaum.

Housen, A. and Simoens, H. (2016). Introduction: Cognitive perspectives on difficulty and complexity in L2 acquisition. Studies in Second Language Acquisition, 38(2), 163175.

Hawkins, J. (1999). Processing complexity and filler-gap dependencies across grammars. Language, 75, 244-285.

Hawkins, R. (2001). Second language syntax: A Generative Introduction. Oxford: Blackwell.

Jach, D. (2018). A Usage-Based approach to preposition placement in English as a second language. Language Learning, 68(1), 271-304.

Kayne, R. (1994). The antisymmetry of syntax. Cambridge, MA: MIT Press.

Keenan, E. and Comrie, B. (1977). Noun phrase accessibility and Universal Grammar. Linguistic Inquiry, 8, 63-100. 
Klein, W., and Perdue, C. (1997). The Basic variety (or: Couldn't natural languages be much simpler?). Second language research, 13(4), 301-347.

Kornfilt, J. (1997). Turkish. London: Routledge.

Kornfilt, J. (2000a). Locating relative agreement in Turkish and Turkic. In C. Kerslake, and A. Göksel (Eds.). Studies in Turkish and Turkic languages, (pp.189-196). Wiesbaden: Harrassowitz Verlag.

Kornfilt, J. (2000). Some syntactic and morphological properties of relative clauses in Turkish. The Syntax of Relative Clauses. In A. Alexiadou, P. Law, A. Meinunger and C. Wilder (eds.). Amsterdam/Philadelphia: John Benjamins, 121-159.

Larsen-Freeman, D. (1997). Chaos/complexity science and second language acquisition. Applied Linguistics 18(2). 141-165.

Larsen-Freeman, D. and Lynne C. (2008). Complex systems and applied linguistics. Oxford: Oxford University Press.

Lee, T. (2016). Dominant language transfer in the comprehension of L 2 learners and heritage speakers. International Journal of Applied Linguistics, 26(2), 190-210.

Lehmann, C. (1986). On the typology of relative clauses. Linguistics, 24(4). 663-680.

MacDonald, M. C. and Christiansen, M. (2002). Reassessing working memory: comment on Just and Carpenter (1992) and Waters and Caplan (1999). Psychological Review, 109, $35-54$.

Mackey, A., and Gass, S. M. (2015). Second language research: Methodology and design. London : Routledge.

Mellow, J. D. (2006). The emergence of second language syntax: A case study of the acquisition of relative clauses. Applied Linguistics, 27(4), 645-670.

Nevo, B. (1985). Face validity revisited. Journal of Educational Measurement, 22(4), $287-$ 293.

Nunan, D. (1996). Issues in second language acquisition research: examining substance and procedure. In W. C. Ritchie and T. K. Bhatia (eds), Handbook of Second Language Acquisition. New York: Ritchie and Bhatia, 349-74.

O'Grady, W. (2011). Relative clauses: Processing and acquisition. In E. Kidd (Ed.), The Acquisition of Relative Clauses: Processing, Typology, and Function (pp. 13-38). Amsterdam: John Benjamins.

O'Grady, W., Lee, M., Choo, M. (2003). A subject-object asymmetry in the acquisition of relative clauses in Korean as a second language. Studies in Second Language Acquisition, 25, 433-448.

Oluwatayo, J. A. (2012). Validity and reliability issues in educational research. Journal of educational and social research, 2(2), 391-400.

Ordem, E. (2017). Acquisition of Zero Relative Clauses in English by Adult Turkish Learners of English. Journal of Education and Training Studies, 5(1), 190-195.

Ordem, E., Özezen, M. Y., Darancık, Y., Mavaşoğlu, K and Hadutuğlu, K. (2018). Syntactic variation of zero object (non-subject) relative clauses: A cross-linguistic perspective. International Journal of Language Academy, 6(5), 391-401. 
Özçelik, Ö. (2006). Processing relative clauses in Turkish as a second language (Doctoral dissertation). University of Pittsburgh, PA, The United States of America.

Özge, D., Marinis, T. and Zeyrek, D. (2015). Incremental processing in head-final child language: online comprehension of relative clauses in Turkish-speaking children and adults. Language, Cognition and Neuroscience, 30(9), 1230-1243.

Roberts, P., and Priest, H. (2006). Reliability and validity in research. Nursing standard, 20(44), 41-46.

Paluluoğlu, N. Ş. (2017). Syntactic processing differences and the effects of memory-load interference for object relative and subject relative clauses in Turkish. Unpublished master thesis, University of Yeditepe, İstanbul.

Perpiñán, S. (2015). L2 grammar and L2 processing in the acquisition of Spanish prepositional relative clauses. Bilingualism: Language and Cognition, 18(4), 577-596.

Rahmany, R. and Haghpour, M. I. N. A. (2015). The effect of relative clause types on processing difficulty. Research Journal of English Language and Literature, 3(2), 3850 .

Ross, J. (1967). Constraints on variables in syntax. Doctoral dissertation, MIT. Reprinted as Infinite Syntax! (1986). Norwood, New Jersey: ABLEX Publishing Corporation.

Sánchez-Walker, N., and Montrul, S. (2016). Comprehension of subject and object relative clauses by second language learners of Spanish. Language Acquisition Beyond Parameters: Studies in honour of Juana M. Liceras, 51, 149-185.

Seliger, H. W. and Shohamy, E. (1989). Second Language Research Methods. London: Oxford University Press.

Sharp, V. (1979). Statistics for the Social Sciences. Boston: Little, Brown.

Skehan P. and Foster P. (1997). The influence of planning and post-task activities on accuracy and complexity in task based learning. Language Teaching Research, 1,3.

Smith, C. (1964). Determiners and Relative Clauses in a Generative Grammar of English. Language 40 (1), 37-52.

Tabor, W., Juliano, C., and Tanenhaus, M. K. (1997). Parsing in a dynamical system: an attractor-based account of the interaction of lexical and structural constraints in sentence processing. Language and Cognitive Processes, 12(2), 211-272.

Tarollo, F. and Myhill, J. (1983). Interference and natural language processing in relative clauses and wh-questions. Studies in Second Language Acquisition, 14, 39-70.

Thornton, H. (2016). An introduction to transformational syntax. London: Routledge

Turan, C. (2012). Degree of access to universal grammar / transfer from L1 in the learning of relative clauses by Turkish learners of English. Unpublished master thesis, University of Hacettepe, Ankara.

Turan, C. (2018). An eye-tracking investigation of attachment preferences to relative clauses in Turkish. Unpublished PhD dissertation, University of Hacettepe, Ankara.

Ulasan, A. R. (2018). University Students' Avoidance Behavior in English Classes. Online Submission, 6(2), 37-44. 
Wiechmann, D. (2015). Understanding relative clauses: A usage-based view on the processing of complex constructions (Vol. 268). Walter de Gruyter $\mathrm{GmbH}$ and $\mathrm{Co}$ KG.: Berlin.

Wilson, W. (1963). Relative Constructions in Dagbani. Journal of African Languages 2 (2), 139-144.

Wu, F., Kaiser, E., and Vasishth, S. (2018). Effects of Early Cues on the Processing of Chinese Relative Clauses: Evidence for Experience-Based Theories. Cognitive science, 42, 1101-1133

Yas, E. (2016). Acquisition of English Relative Clauses by German L1 and Turkish L1 Speakers (Doctoral dissertation). Südwestdeutsche Verlag für Hochschulschriften, Germany.

Yip, V., and Matthews, S. (1991). Relative Complexity: Beyond Avoidance. CUHK Papers in Linguistics, 3, 112-124.

Young, S. K. (2018). Relation between Frequency and Processing Difficulty of English Relative Clauses by L2 Learners: A Learner Corpus Analysis. 언어연구, 34(3), 491504.

Yun, J., Chen, Z., Hunter, T., Whitman, J., and Hale, J. (2015). Uncertainty in processing relative clauses across East Asian languages. Journal of East Asian Linguistics, 24(2), 113-148. 